\title{
Use of Partial Host Resistance in the Management of Bacterial Blight of Rice
}

\author{
Tika B. Adhikari, Agriculture and Agri-Food Canada, Saskatoon Research Centre, 107 Science Place, Saskatoon, \\ SK S7N 0X2, Canada; Anil Shrestha, Department of Plant Agriculture, University of Guelph, Ontario, N1G 2W1 \\ Canada; Ram Chandra Basnyat, Department of Plant Pathology, Institute of Agriculture and Animal Science \\ (IAAS), Tribhuvan University, P.O. Box 984, Kathmandu, Nepal and T. W. Mew, Division of Entomology and \\ Plant Pathology, International Rice Research Institute (IRRI), MCPO Box 3127, 1271 Makati City, Philippines
}

\begin{abstract}
Adhikari, T. B., Shrestha, A., Basnyat, R. C., and Mew, T. W. 1999. Use of partial host resistance in the management of bacterial blight of rice. Plant Dis. 83:896-901.

The progress of bacterial blight epidemics, caused by Xanthomonas oryzae pv. oryzae, varies with environment. The irrigated lowland rice production environment in central Terai (plain) is less conducive to the disease than the irrigated lowland rice production environment in eastern Terai in Nepal. The effect of partial resistance on bacterial blight was studied in central Terai during the wet seasons of 1994, 1995, and 1996. Three partially resistant rice cultivars, Sabitri, Laxmi, and IR54 (possessing the Xa4 gene), and susceptible check IR24 were included in this study. Analysis of pooled data from the 3 years of experiments indicated that rice cultivars differed in resistance based on three epidemiological parameters: disease severity (DS), area under the disease progress curve (AUDPC), and rate of disease increase (r). Estimates of DS, AUDPC, and $r$ were reduced and yield loss was negligible in the partially resistant cultivar Laxmi compared with the susceptible check IR24. IR54, which has partial resistance to $X$. oryzae pv. oryzae, also showed low DS, AUDPC, and r, which prevented yield loss due to bacterial blight. The locally adapted cultivar Sabitri showed intermediate estimates of DS, AUDPC, r, and yield loss. Earlier and more severe disease developed in the susceptible check IR24, resulting in a yield loss of $22 \%$. Yield losses were mainly due to reductions in number of tillers, number of grains per panicle, and 1,000-grain weight. These data indicate that the use of rice cultivars with high levels of partial resistance will be an effective tool for the management of bacterial blight in central Terai and similar environments in Nepal.
\end{abstract}

Bacterial blight, caused by Xanthomonas oryzae pv. oryzae (25), is a common and destructive disease of rice (Oryza sativa) in Asia. The disease can cause yield losses of 20 to $60 \%(6,10,22)$. The use of resistant cultivars is economical and the best approach for bacterial blight management. Twenty-one resistance genes ( $\mathrm{X} a$ genes) for bacterial blight have been identified and used in breeding programs $(13,20)$. At the International Rice Research Institute (IRRI), Philippines, the bacterial blight resistance gene $\mathrm{Xa} 4$ was first incorporated into improved rice cultivars during the early 1970s (13). Although there was a shift in the racial population of $X$. oryzae pv. oryzae for increased virulence on IR cultivars carrying the $\mathrm{Xa} 4$ gene, no major bacterial blight epidemics have been reported on these cultivars $(15,16,18)$

Corresponding author: T. B. Adhikari

E-mail: tadhikari@sprint.ca

Accepted for publication 12 July 1999.

Publication no. D-1999-0819-01R

(C) 1999 The American Phytopathological Society
Parlevliet (23) described partial resistance as a form of incomplete resistance in which fungal spore production is reduced even though the host plant is susceptible to infection. With some diseases of cereal crops, such partial resistance has been associated with durable resistance (12). Analysis of components of partial host resistance to bacterial diseases is difficult. The selection of partial resistance to $X$. oryzae pv. oryzae has been based on the development of shorter lesions or reduced disease severity when compared with a susceptible check.

In Nepal, bacterial blight is regarded as a major disease of rice $(2,7)$. Although this disease occurs throughout the country, it is known to be more severe in the Terai (plain) than in the mid-hills of Nepal (7). A collection of $45 X$. oryzae pv. oryzae strains from Nepal was analyzed by virulence typing and DNA fingerprinting by restriction fragment length polymorphism analysis (RFLP) using insertion sequence (IS) element IS1112 (27) and a family of avirulence genes as probes (11). This analysis suggested that genetic diversity of the pathogen population was higher in Nepal than in most other Asian countries (8). Recently, the diversity of 171 strains of
$X$. oryzae pv. oryzae collected from the eight rice-producing zones in Nepal was analyzed by two polymerase chain reaction (PCR)-based assays. Multiple correspondence analysis based on PCR assays of the pathogen's genome grouped the collection into 31 molecular haplotypes and five putative genetic lineages (4). Most strains of $X$. oryzae pv. oryzae from Nepal were virulent to rice cultivars containing bacterial blight resistance genes $X a 4, x a 5$, and Xal0 $(1,4,5,8)$, the genes present in the commonly used IRRI rice differential cultivars.

In our earlier studies, bacterial blight severity and yield loss were significantly reduced on the rice cultivars IR36, IR54, and IR1695, possessing either $\mathrm{Xa4}$ or $\mathrm{Xa3}$, compared with the susceptible check IR24 (6). Although races or pathotypes of $X$. oryzae pv. oryzae identified in Nepal were compatible with rice cultivars that carried the Xa4 gene in greenhouse studies $(4,5,8)$, the value of this gene for managing bacterial blight under field conditions is relatively unknown. Among local rice cultivars, Sabitri and Laxmi were the least susceptible to bacterial blight in Nepal (3). However, assessment of partial resistance to $X$. oryzae pv. oryzae in these cultivars had not been fully explored in the field. Since high levels of resistance to Nepalese isolates of $X$. oryzae pv. oryzae have not been found in rice, and the irrigated lowland rice production environment in central Terai does not favor severe development of bacterial blight, it may be possible to manage this disease with partially resistant rice cultivars in such an environment. The objective of this study was to assess the utility of partial resistance to $X$. oryzae pv. oryzae as a tool in the management of bacterial blight of rice in Nepal.

\section{MATERIALS AND METHODS}

Selection of site. The environment in central and western Terai is less conducive to bacterial blight development than that in eastern Terai (Jhapa, Morang, and Sunsari) $(2,7)$. In all 3 years, the experimental site was located at the research farm of the Institute of Agriculture and Animal Science (IAAS), Chitwan ( $27^{\circ} 37^{\prime} \mathrm{N}$; 84 $24^{\circ}$ E; $256 \mathrm{~m})$, Nepal, which represents an 
important rice growing area of central Terai in Nepal and has the subtropical irrigated lowland rice production environment. The soil at the experimental site was sandy loam with a $\mathrm{pH}$ of 5.4. The experiments were conducted during the 1994, 1995, and 1996 rice growing seasons (June to September).

Selection of rice cultivars. The rice cultivars Sabitri, Laxmi, IR54, and IR24 were chosen based on results from previous experiments $(3,6)$. These cultivars differ in bacterial blight resistance, plant height, and yield, and they are all grown commercially. The locally adapted rice cultivars Sabitri and Laxmi were selected to represent partially resistant cultivars grown in Nepal. IR54 was chosen because it possesses the $\mathrm{Xa} 4$ gene and has been shown to be partially resistant to $X$. oryzae pv. oryzae in the Philippines (6). IR24 was used as a susceptible check. The maturity periods for all four rice cultivars ranged from 118 to 120 days.

Inoculum and inoculation. The isolate NX0382 of X. oryzae pv. oryzae, which was collected from Chitwan and is characterized as pathotype 1 and lineage 4 (4), was used in assays in all 3 years of the study. Prior to inoculation, small bottles containing $100 \mathrm{ml}$ of peptone sucrose agar (PSA) (22) were seeded with $X$. oryzae pv. oryzae and incubated at $28^{\circ} \mathrm{C}$ for $72 \mathrm{~h}$. Bacterial cells were scraped with a wire loop and resuspended in $100 \mathrm{ml}$ of sterile distilled water per bottle. The bacterial suspension was adjusted to approximately $2 \times 10^{8} \mathrm{CFU} / \mathrm{ml}$ using a spectrophotometer. Rice seedlings (21 day old) were sprayinoculated with bacterial suspension (approximately $5 \mathrm{ml}$ per seedling) in the evening and transplanted into the experimental plots the following morning. Seedlings sprayed with sterile distilled water served as the control.

Experimental design and treatments. All experiments entailed a split-plot design with four replicates. The main plot treatments were based on inoculation or noninoculation with the bacterial blight pathogen, and the subplot treatments were the four rice cultivars. Each main plot was $4 \mathrm{~m}$ long and $4 \mathrm{~m}$ wide, with a $0.75-\mathrm{m}$ border between the subplots. Rice cultivars were arranged randomly in each subplot, and within each subplot, two seedlings per rice cultivar were transplanted at $20 \times 20 \mathrm{~cm}$ spacing. Transplanting was done on 14 June in all 3 years. Locally recommended agronomic practices and weed and insect control measures were followed. Nitrogen $(\mathrm{N})$ fertilizer was applied at the rate of $120 \mathrm{~kg} / \mathrm{ha}$ in the form of ammonium sulfate, $50 \%$ at transplanting and $50 \%$ at 45 days after transplanting. Zinc deficiency was observed 2 weeks after transplanting and corrected by applying zinc sulfate at the rate of $5 \mathrm{~kg} / \mathrm{ha}$.

Disease assessments. Disease assessments were made as described previously (6). Briefly, 10 hills (clump of two plants) were arbitrarily selected from the center rows of each subplot and used for disease assessments. Ten leaves per hill were examined eight times at 10-day intervals beginning 30 days after transplanting. The leaves assessed in each hill were at different levels in the canopy. Disease severity (DS), expressed as percent diseased leaf area, was estimated for each inoculated plot. Area under the disease progress curve (AUDPC) was estimated from disease severity values using the method of Shaner and Finney (24).

Yield and yield components. Grain yield and yield components were deter- mined from a $1-\mathrm{m}^{2}$ nondestructive sampling area at the center of each plot. At maturity, 20 hills from the uninoculated and inoculated plots were harvested manually to determine number of tillers and plot yield. Thirty panicles were randomly selected from the plants harvested from each plot to determine yield components such as number of grains per panicle and 1,000grain weight $(\mathrm{g})$ for each rice cultivar. All grains were combined, air-dried, and then weighed. Grain yield per square meter was converted into kilograms per hectare $(\mathrm{kg} / \mathrm{ha})$ at $14 \%$ moisture. The percent yield loss was calculated by using the formula:

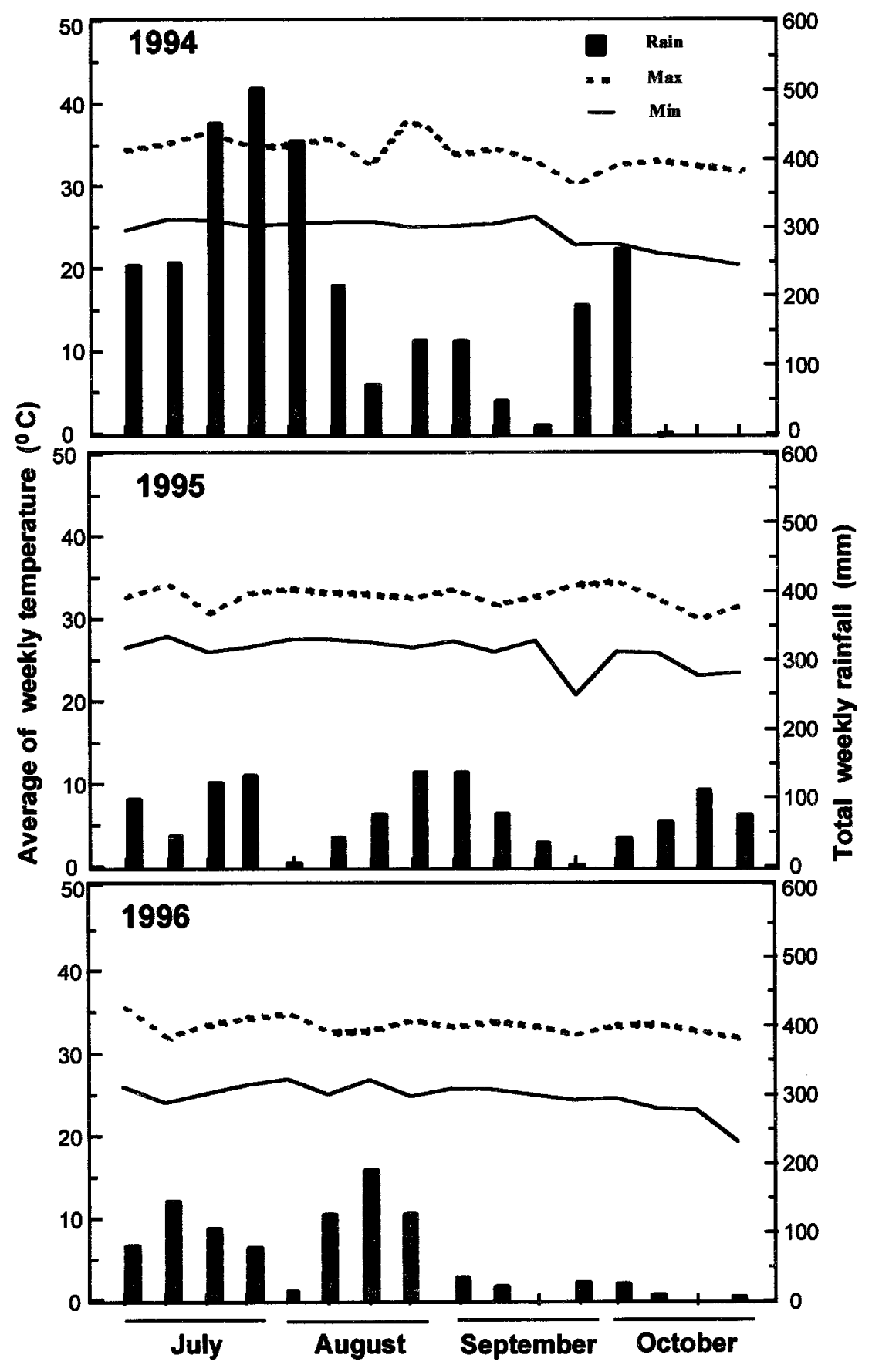

Fig. 1. Average minimum and maximum temperatures $\left({ }^{\circ} \mathrm{C}\right)$ and rainfall $(\mathrm{mm})$ during the rice growing seasons in 1994, 1995, and 1996 in Chitwan, Nepal. 
$\%$ Yield loss $=[$ (yield of uninoculated control plot - yield of infected plot)/yield of uninoculated control plot] $\times 100$.

Weather data. Minimum and maximum temperatures $\left({ }^{\circ} \mathrm{C}\right)$ and rainfall $(\mathrm{mm})$ were recorded weekly in all 3 years. These data were collected for each rice growing season from the weather station located at IAAS, Chitwan.

Data analyses. Disease progress curves for DS expressed as percent diseased leaf area were plotted for each cultivar.

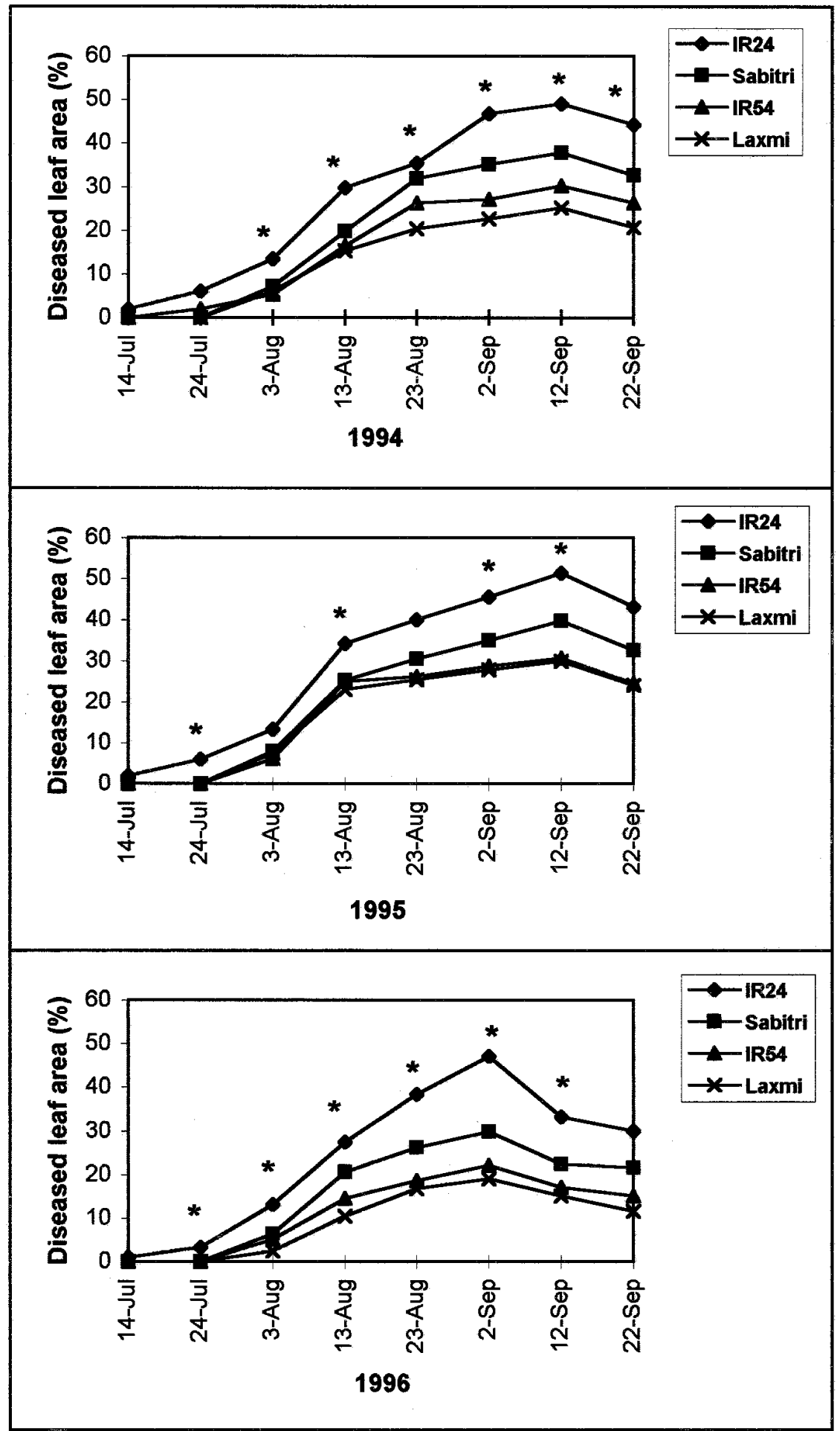

Fig. 2. Bacterial blight progress on four rice cultivars inoculated with Xanthomonas oryzae pv. oryzae in Chitwan, Nepal. Ten leaves per hill (clump of two plants) were assessed at different levels in the canopy from each replicate 30 days after transplanting. Disease severity (\%) was calculated from 10 arbitrarily selected hills at 10-day intervals per replicate. Values are means of four replicates. An asterisk along the upper side of the $\mathrm{x}$-axis signifies that means among rice cultivars at each disease assessment time indicated were significantly different $(P \leq 0.05)$ according to the least significant difference test.

AUDPC was calculated for each subplot and standardized by the number of days in the epidemic (9). Linearized forms of the exponential, Gompertz, and logistic models were fitted to disease progress data (percent disease severity) for each replicate of each cultivar. Criteria for selecting the best fitting model included examination of observed and predicted DS versus time, coefficient of determination $\left(R^{2}\right)$ values for each model, standard errors of the parameter estimates, and $F$ statistic testing the significance of the regression model $(P$ $\leq 0.05)$. The $R^{2}$ value of the regression equations of each cultivar in each experiment indicated the proportion of total variation explained by the regression model. Based on examination of these models, the logistic model was determined to be the most appropriate and was used for further analysis of apparent infection rate. Apparent infection rate (r), expressed in logit units per day, was calculated by converting disease severity values to proportions on a scale of 0 to 1 and then transforming the data into logit (26). Data for DS, AUDPC, r, yield, and yield components were analyzed by analysis of variance (ANOVA) using the general linear model procedure of the Statistical Analysis System (Ver. 6.1, SAS Institute, Cary, NC). Cultivar differences were further evaluated by Fisher's protected least significant difference (LSD). AUDPC was the most reliable parameter for assessing resistance to $X$. oryzae pv. oryzae, compared with the other measures of disease such as DS or $r$ (6). Therefore, correlation coefficients were computed for yield and yield components for each cultivar and for rainfall data across the years in relation to AUDPC values.

\section{RESULTS}

The amount of rainfall received during the $1994(3,131 \mathrm{~mm})$ season was higher than during the $1995(1,187 \mathrm{~mm})$ or 1996 $(1,124 \mathrm{~mm})$ season (Fig. 1). No distinct temperature patterns were observed across years. Differences in bacterial blight severity (percent diseased leaf area) were evident among rice cultivars, particularly in 1994 and 1996 (Fig. 2). Bacterial blight progression was highest in IR24, modest in Sabitri, and lowest in IR54 and Laxmi in all 3 years. Estimates for DS, AUDPC, and $r$ were lower in the three partially resistant rice cultivars than in the susceptible check IR24 across years (Table 1). In 1994 and 1995, there were fewer tillers on IR24 than on the other cultivars (Table 2). In 1996, tiller loss was negligible in Laxmi, whereas tiller loss was greater than $10 \%$ in IR24, Sabitri, and IR54. In all 3 years, percent reduction in the number of grains per panicle was higher in IR24 than in the three partially resistant cultivars (Table 3 ). Bacterial blight reduced 1,000-grain weight in IR24 and Sabitri, but no significant reductions in 1,000-grain weight were 
observed for IR54 and Laxmi in all 3 years (Table 4). In 1994, under no disease pressure, grain yield of IR24, Sabitri, IR54, and Laxmi were similar (Table 5). Under disease pressure, however, IR24 suffered greater yield loss than the other cultivars in 1994 and ranked the lowest in yield. In contrast, Laxmi ranked among the highest in yield under both no disease and disease conditions. In 1995 and 1996, yield loss was higher in IR24 than observed in Sabitri, IR54, and Laxmi (Table 5).

Correlation analysis. Highly positive correlations existed between AUDPC values and percent reduction in number of tillers, number of grains per panicle, 1,000grain weight, and yield among four rice cultivars tested (Table 6). AUDPC values also were correlated with rainfall in 1994 $(r=0.53)$ and in $1995(r=0.60)$.

\section{DISCUSSION}

In this study, epidemic development of bacterial blight on four selected rice cultivars was examined to determine the effect of partial resistance to $X$. oryzae pv. oryzae on the rate of disease progress and yield loss. Differences in resistance were evident among four rice cultivars tested. Laxmi and IR54 possessed high levels of partial resistance to $X$. oryzae pv. oryzae and were effective in reducing bacterial blight epidemics.

Bacterial blight development and yield loss were high for the susceptible check IR2 4 over the 3 years of study. In contrast, a marked reduction in the rate of disease progress in Laxmi suggests that this cultivar possessed the highest level of partial resistance to $X$. oryzae pv. oryzae among cultivars tested, and may have the best available resistance to $X$. oryzae pv. oryzae in Nepal. The level of partial resistance in Laxmi was sufficient to prevent yield loss attributable to bacterial blight under conditions where the susceptible check IR24 was heavily infected. Although Laxmi was released in 1972 by the National Rice Research Program, Parwanipur, Nepal, inheritance of resistance to $X$. oryzae pv. oryzae in this cultivar has not yet been determined.

IR54, which has the Xa4 gene, also showed no significant yield loss attribut-

Table 1. Area under the disease progress curve (AUDPC), maximum disease severity (DS), and apparent infection rate (r) on four rice cultivars inoculated with Xanthomonas oryzae pv. oryzae in Nepal

\begin{tabular}{|c|c|c|c|c|c|c|c|c|c|}
\hline \multirow[b]{2}{*}{ Cultivar } & \multicolumn{3}{|c|}{ AUDPC $^{x}$} & \multicolumn{3}{|c|}{ Disease severity $(\%)^{\mathrm{x}}$} & \multicolumn{3}{|c|}{ Infection rate $(r)^{y}$} \\
\hline & 1994 & 1995 & 1996 & 1994 & 1995 & 1996 & 1994 & 1995 & 1996 \\
\hline IR24 & $335.1 \mathrm{a}^{\mathrm{z}}$ & $298.0 \mathrm{a}$ & $280.0 \mathrm{a}$ & $49.0 \mathrm{a}$ & $51.4 \mathrm{a}$ & $47.0 \mathrm{a}$ & $0.029 \mathrm{a}$ & $0.039 \mathrm{a}$ & $0.046 \mathrm{a}$ \\
\hline Sabitri & $254.9 \mathrm{~b}$ & $225.4 \mathrm{~b}$ & $182.8 \mathrm{~b}$ & $37.7 \mathrm{~b}$ & $42.7 \mathrm{~b}$ & $29.8 \mathrm{~b}$ & $0.014 \mathrm{ab}$ & $0.017 \mathrm{~b}$ & $0.023 \mathrm{~b}$ \\
\hline IR54 & $200.7 \mathrm{c}$ & $133.1 \mathrm{c}$ & $140.6 \mathrm{c}$ & $30.2 \mathrm{c}$ & $30.6 \mathrm{c}$ & $25.0 \mathrm{c}$ & $0.008 \mathrm{~b}$ & $0.010 \mathrm{~b}$ & $0.014 \mathrm{~b}$ \\
\hline Laxmi & $167.0 \mathrm{~d}$ & $113.0 \mathrm{c}$ & $145.2 \mathrm{c}$ & $25.3 \mathrm{~d}$ & $33.2 \mathrm{c}$ & $26.5 \mathrm{bc}$ & $0.013 \mathrm{ab}$ & $0.019 \mathrm{~b}$ & $0.018 \mathrm{~b}$ \\
\hline
\end{tabular}

${ }^{\mathrm{x}}$ AUDPC-\%-day was calculated using severity values only for day 80 and day 90 after transplanting: $\left[\left(\mathrm{DS}_{80}+\mathrm{DS}_{90}\right) / 2\right] \times 10$. Each value represents the mean of four replicates.

${ }^{\mathrm{y}} \mathrm{r}$ (units/day) was calculated based only on logit severities at 80 and 90 days after transplanting.

${ }^{\mathrm{z}}$ Values in the same column followed by the same letter are not significantly different $(P \leq 0.05)$ based on Fisher's protected LSD.

Table 2. Comparison of number of tillers per hill (clump of 2 plants) of four rice cultivars inoculated with Xanthomonas oryzae pv. oryzae in Nepal ${ }^{\mathrm{x}}$

\begin{tabular}{|c|c|c|c|c|c|c|c|c|c|}
\hline \multirow[b]{2}{*}{ Cultivar } & \multicolumn{3}{|c|}{1994} & \multicolumn{3}{|c|}{1995} & \multicolumn{3}{|c|}{1996} \\
\hline & Control & Diseased & $\operatorname{Loss}(\%)^{y}$ & Control & Diseased & Loss $(\%)$ & Control & Diseased & Loss $(\%)$ \\
\hline IR24 & $8.7 \mathrm{~b}^{\mathrm{z}}$ & $6.9 \mathrm{~b}$ & $20.2^{*}$ & $9.2 \mathrm{a}$ & $7.9 \mathrm{~b}$ & $14.9 *$ & $7.2 \mathrm{~b}$ & $6.3 \mathrm{~b}$ & $12.1^{*}$ \\
\hline Sabitri & $8.9 \mathrm{~b}$ & $8.0 \mathrm{ab}$ & 9.6 & $8.1 \mathrm{a}$ & $7.3 \mathrm{~b}$ & 9.9 & $7.1 \mathrm{~b}$ & $6.4 \mathrm{~b}$ & $10.2^{*}$ \\
\hline IR54 & $10.7 \mathrm{a}$ & $9.8 \mathrm{a}$ & 7.8 & $8.6 \mathrm{a}$ & $8.3 \mathrm{a}$ & 3.5 & $7.2 \mathrm{~b}$ & $6.4 \mathrm{~b}$ & $10.5^{*}$ \\
\hline Laxmi & $9.9 \mathrm{a}$ & $9.3 \mathrm{a}$ & 6.5 & $8.9 \mathrm{a}$ & $8.2 \mathrm{a}$ & 7.9 & $8.6 \mathrm{a}$ & $8.6 \mathrm{a}$ & 0.4 \\
\hline
\end{tabular}

${ }^{x}$ Mean value obtained from 20 hills per treatment.

y Percent loss when compared with noninoculated control, $*=$ significantly different $(P \leq 0.05)$.

z Values in the same column followed by the same letter are not significantly different $(P \leq 0.05)$ based on Fisher's protected LSD.

Table 3. Comparison of number of grains per panicle of four rice cultivars infected by Xanthomonas oryzae pv. oryzae in Nepal ${ }^{\mathrm{x}}$

\begin{tabular}{|c|c|c|c|c|c|c|c|c|c|}
\hline \multirow[b]{2}{*}{ Cultivar } & \multicolumn{3}{|c|}{1994} & \multicolumn{3}{|c|}{1995} & \multicolumn{3}{|c|}{1996} \\
\hline & Control & Diseased & $\operatorname{Loss}(\%)^{y}$ & Control & Diseased & Loss $(\%)$ & Control & Diseased & Loss $(\%)$ \\
\hline IR24 & $76.2 \mathrm{ab}^{\mathrm{z}}$ & $57.5 \mathrm{ab}$ & $24.5^{*}$ & $106.2 \mathrm{ab}$ & $94.2 \mathrm{ab}$ & $11.3^{*}$ & $78.9 \mathrm{c}$ & $60.7 \mathrm{c}$ & $23.1 *$ \\
\hline Sabitri & $53.9 \mathrm{~b}$ & $51.3 \mathrm{~b}$ & 4.8 & $101.1 \mathrm{ab}$ & $95.4 \mathrm{ab}$ & 5.6 & $88.1 \mathrm{a}$ & $80.2 \mathrm{a}$ & 9.0 \\
\hline IR54 & $54.2 \mathrm{~b}$ & $50.4 \mathrm{~b}$ & 7.0 & $95.1 \mathrm{~b}$ & 87.4 b & 8.1 & $83.7 \mathrm{~b}$ & $82.4 \mathrm{a}$ & 1.5 \\
\hline Laxmi & 88.8 a & $83.1 \mathrm{a}$ & 6.4 & $108.8 \mathrm{a}$ & $104.7 \mathrm{a}$ & 3.8 & $73.4 \mathrm{~d}$ & $70.7 \mathrm{~b}$ & 3.7 \\
\hline
\end{tabular}

x Mean value obtained from 30 panicles per treatment.

y Percent loss when compared with noninoculated control, $*=$ significantly different $(P \leq 0.05)$.

${ }^{z}$ Values in the same column followed by the same letter are not significantly different $(P \leq 0.05)$ based on Fisher's protected LSD.

Table 4. Comparison of 1,000-grain weight (g) of four rice cultivars inoculated with Xanthomonas oryzae pv. oryzae in Nepal ${ }^{\mathrm{x}}$

\begin{tabular}{|c|c|c|c|c|c|c|c|c|c|}
\hline \multirow[b]{2}{*}{ Cultivar } & \multicolumn{3}{|c|}{1994} & \multicolumn{3}{|c|}{1995} & \multicolumn{3}{|c|}{1996} \\
\hline & Control & Diseased & $\operatorname{Loss}(\%)^{y}$ & Control & Diseased & Loss $(\%)$ & Control & Diseased & Loss $(\%)$ \\
\hline IR24 & $19.0 \mathrm{a}^{\mathrm{z}}$ & $12.0 \mathrm{c}$ & $36.8^{*}$ & $23.3 \mathrm{a}$ & $19.0 \mathrm{a}$ & $18.6^{*}$ & $27.7 \mathrm{a}$ & $18.7 \mathrm{~b}$ & $32.5^{*}$ \\
\hline Sabitri & $15.7 \mathrm{~b}$ & $13.3 \mathrm{~b}$ & $14.9 *$ & $20.0 \mathrm{~b}$ & $16.7 \mathrm{~b}$ & $16.7 *$ & $25.3 \mathrm{~b}$ & $21.7 \mathrm{a}$ & $14.5^{*}$ \\
\hline IR54 & $15.0 \mathrm{~b}$ & $14.3 \mathrm{~b}$ & 4.5 & $20.0 \mathrm{~b}$ & $18.3 \mathrm{a}$ & 8.4 & $20.3 \mathrm{c}$ & $19.0 \mathrm{~b}$ & 6.5 \\
\hline Laxmi & $18.0 \mathrm{a}$ & $16.7 \mathrm{a}$ & 7.3 & $20.1 \mathrm{~b}$ & $18.7 \mathrm{a}$ & 7.2 & $23.7 \mathrm{~b}$ & $22.0 \mathrm{a}$ & 7.0 \\
\hline
\end{tabular}

${ }^{\mathrm{x}}$ Mean value obtained from 30 panicles per treatment.

y Percent loss when compared with noninoculated control, $*=$ significantly different $(P \leq 0.05)$.

${ }^{z}$ Values in the same column followed by the same letter are not significantly different $(P \leq 0.05)$ based on Fisher's protected LSD. 
Table 5. Grain yield (kg/ha) and yield loss (\%) of four rice cultivars inoculated with Xanthomonas oryzae pv. oryzae in Nepal

\begin{tabular}{|c|c|c|c|c|c|c|c|c|c|}
\hline \multirow[b]{2}{*}{ Cultivar } & \multicolumn{3}{|c|}{1994} & \multicolumn{3}{|c|}{1995} & \multicolumn{3}{|c|}{1996} \\
\hline & Control & Diseased & $\operatorname{Loss}(\%)^{\mathrm{y}}$ & Control & Diseased & Loss $(\%)$ & Control & Diseased & Loss $(\%)$ \\
\hline IR24 & $3,700 \mathrm{a}^{\mathrm{z}}$ & $3,000 \mathrm{c}$ & $22.3^{*}$ & $3,600 \mathrm{~b}$ & $3,000 \mathrm{~b}$ & $14.9 *$ & $3,500 \mathrm{~b}$ & $2,900 \mathrm{~b}$ & $18.3^{*}$ \\
\hline Sabitri & $3,900 \mathrm{a}$ & $3,500 \mathrm{~b}$ & 10.3 & $3,800 \mathrm{a}$ & $3,700 \mathrm{a}$ & 3.7 & $3,700 \mathrm{a}$ & $3,400 \mathrm{a}$ & 6.3 \\
\hline IR54 & $3,600 \mathrm{a}$ & $3,400 \mathrm{~b}$ & 4.7 & $3,800 \mathrm{a}$ & $3,700 \mathrm{a}$ & 4.4 & $3,800 \mathrm{a}$ & $3,600 \mathrm{a}$ & 5.3 \\
\hline Laxmi & $3,900 \mathrm{a}$ & $3,800 \mathrm{a}$ & 3.3 & $3,800 \mathrm{a}$ & $3,600 \mathrm{a}$ & 3.2 & $3,800 \mathrm{a}$ & $3,700 \mathrm{a}$ & 2.6 \\
\hline
\end{tabular}

y Percent loss when compared with noninoculated control, * = significantly different $(P \leq 0.05)$.

z Values in the same column followed by the same letter are not significantly different $(P \leq 0.05)$ based on Fisher's protected LSD.

Table 6. Correlation coefficients ${ }^{\mathrm{y}}$ for area under the disease progress curve (AUDPC), percent reductions in tiller number, grain number, 1,000-grain weight, and yield $(\mathrm{kg} / \mathrm{ha})$ of inoculated plots of four rice cultivars in Nepal

\begin{tabular}{llcc}
\hline & & AUDPC & \\
\cline { 2 - 4 } Percent reduction & $\mathbf{1 9 9 4}$ & $\mathbf{1 9 9 5}$ & $\mathbf{1 9 9 6}$ \\
\hline Tiller number & $0.63^{* *}$ & $0.72^{* * *}$ & $0.61^{* *}$ \\
Grains per panicle & $0.54^{*}$ & $0.72^{* *}$ & $0.63^{* *}$ \\
1,000 -grain weight & $0.65^{* *}$ & $0.76^{* *}$ & $0.66^{* *}$ \\
Yield & $0.64^{* *}$ & $0.77^{* *}$ & $0.63^{* *}$ \\
\hline
\end{tabular}

y Coefficients are statistically significant at $P \leq 0.05(*), P \leq 0.01(* *)$.

z AUDPC-\%-day was calculated using severity values only for day 80 and day 90 after transplanting:

$\left[\left(\mathrm{DS}_{80}+\mathrm{DS}_{90}\right) / 2\right] \times 10$. Each value represents the mean of four replicates.

able to bacterial blight in the 3 years of this study. Although infection by $X$. oryzae pv. oryzae occurred each year, bacterial blight development was consistently low in IR54, and the level of partial resistance in IR54 was sufficient to reduce disease severity and prevent yield loss. Bacterial blight epidemics have occurred in many countries in tropical Asia $(15,16)$. However, bacterial blight has not been a major problem on IR cultivars carrying the $\mathrm{Xa} 4$ gene for resistance $(6,21)$. This was presumably attributed to background resistance (17), which resulted when IR cultivars possessing the $\mathrm{Xa} 4$ gene were back-crossed into each of several cultivars that already had moderate resistance to bacterial blight. Furthermore, the presence of the $\mathrm{Xa} 4$ gene and several other factors in IR cultivars may contribute to quantitative resistance (14).

The partially resistant cultivar Sabitri was more susceptible to bacterial blight than was Laxmi. Although bacterial blight severity in Sabitri was less than in the susceptible IR24 control, yield loss tended to be higher than in Laxmi. Thus, there is no assurance that the partial resistance in the cultivar Sabitri will continue to be effective, especially where a virulent indigenous population of $X$. oryzae $\mathrm{pv}$. oryzae is present $(1,4)$.

Yield is the product of three components: number of tillers, number of grains per panicle, and 1,000-grain weight. These components were evaluated to determine which were most severely affected by bacterial blight. In this study, all three yield components were reduced by bacterial blight. Correlation analysis also indicated that percent reduction in number of tillers, number of grains per panicle, and 1,000-grain weight were highly correlated with AUDPC values. Variability was observed among the four rice cultivars for both number of grains per panicle and 1,000-grain weight under disease pressure. Reductions in 1,000-grain weight ranged from 5 to $37 \%$ (Table 4), while reductions in number of grains per panicle ranged from 2 to $25 \%$ (Table 3). However, for most of the cultivars across years, reductions in 1,000-grain weight were greater than reductions in the number of grains per panicle or number of tillers. Grain weight is the yield component most affected by bacterial blight because of the timing of disease development.

With the exception of IR54, grain yields for both noninoculated control and inoculated treatments were consistently higher in 1994 than in either 1995 or 1996 . In general, yield is correlated with total rainfall during the growing season in the lowland rice production environment. Low rainfall and number of days with rain limit bacterial blight development $(6,19)$. In this study, we did not observe differences in temperature patterns. Rainfall was highest in the 1994 and 1995 growing seasons and was correlated with high AUDPC values. Significant correlation also was demonstrated between rainfall and AUDPC in the Philippines (6).

In Nepal, rice production environments are diverse and vary in conduciveness to bacterial blight. Thus, environment must be considered when assessing the relative durability of partial resistance to $X$. oryzae pv. oryzae. Our experimental site was representative of an area less conducive to bacterial blight than eastern Terai. Thus, we recommend the use of partial resistance to $X$. oryzae pv. oryzae for similar environments to manage this disease in Nepal. Further study is required to determine if partial resistance will be as effective in managing bacterial blight in highly conducive environments such as eastern Terai in Nepal.

\section{ACKNOWLEDGMENTS}

This research was supported in part by the Rockefeller Foundation, USA, and the Institute of Agriculture and Animal Science (IAAS), Tribhuvan University, Nepal. We thank Jan Leach, Mark Mazzola, and Eric Pedersen for reviewing the manuscript.

\section{LITERATURE CITED}

1. Adhikari, T. B., Basnyat, R. C., and Mew, T. W. 1999. Virulence of Xanthomonas oryzae pv. oryzae on rice lines containing single resistance genes and gene combinations. Plant Dis. 83:46-50.

2. Adhikari, T., Leach, J., and Mew, T. W. 1996. Bacterial blight of rice and its control in $\mathrm{Ne}$ pal. Integr. Pest Mange. Rev. 1:91-95.

3. Adhikari, T. B., and Mew, T. W. 1994. Resistance of rice to Xanthomonas oryzae pv oryzae in Nepal. Plant Dis. 78:64-67.

4. Adhikari, T. B., Mew, T. W., and Leach, J. E. 1999. Genotypic and pathotypic diversity in Xanthomonas oryzae pv. oryzae in Nepal. Phytopathology 89:687-694.

5. Adhikari, T. B., Mew, T. W., and Teng, P. S. 1994. Phenotypic diversity of Xanthomonas oryzae pv. oryzae in Nepal. Plant Dis. 78:6872 .

6. Adhikari, T. B., Mew, T. W., and Teng, P. S 1994. Progress of bacterial blight on rice cultivars carrying different $X a$ genes for resistance in the field. Plant Dis. 78:73-77.

7. Adhikari, T. B., and Shrestha, S. M. 1989. Distribution and severity of bacterial blight of rice in Nepal. J. Inst. Agric. Anim. Sci. 10:3138 .

8. Adhikari, T. B., Vera Cruz, C. M., Zhang, Q., Nelson, R. J., Skinner, D. Z., Mew, T. W., and Leach, J. E. 1995. Genetic diversity of Xanthomonas oryzae pv. oryzae in Asia. Appl. Environ. Microbiol. 61:966-971.

9. Campbell, C. L., and Madden, L. V. 1990 Introduction to Plant Disease Epidemiology. John Wiley \& Sons, New York.

10. Exconde, O. R., Opina, O. S., and Phanomsawara, A. 1971. Yield losses due to bacterial leaf blight. Philipp. Agric. 57:120-140.

11. Hopkins, C. M., White, F. F., Choi, S. H., Guo, A., and Leach, J. E. 1992. A family of avirulence genes from Xanthomonas oryzae pv. oryzae. Mol. Plant-Microbe Interact. 5:451-459.

12. Johnson, R. 1981. Durable resistance: Definition of, genetic control, and attainment in plant breeding. Phytopathology 71:567-568.

13. Khush, G. S., Mackill, D. J., and Sindhu, G. S. 1989. Breeding rice resistance to bacterial blight. Pages 207-217 in: Bacterial Blight of Rice. International Rice Research Institute, Manila, Philippines.

14. Koch, M., and Parlevliet, J. 1991. Genetic analysis of, and selection for, factors affecting quantitative resistance to Xanthomonas campestris pv. oryzae in rice. Euphytica 53:235245.

15. Mew, T. W. 1987. Current status and future prospects of research on bacterial blight of rice. Annu. Rev. Phytopathol. 25:359-382.

16. Mew, T. W. 1989. An overview of the world bacterial blight situation. Pages 7-12 in: Bac- 
terial Blight of Rice. International Rice Research Institute, Manila, Philippines.

17. Mew, T. W., and Vera Cruz, C. M. 1988. Background resistance to bacterial blight (BB) hill and leaf infection. Int. Rice Res. Newsl. 13(2):11-12.

18. Mew, T. W., Vera Cruz, C. M., and Medalla, E. S. 1992. Changes in race frequency of Xanthomonas oryzae pv. oryzae in response to rice cultivars planted in the Philippines. Plant Dis. 76:1029-1032.

19. Mizukami, T., and Wakimoto, S. 1969. Epidemiology and control of bacterial leaf blight of rice. Annu. Rev. Phytopathol. 7:51-72.

20. Ogawa, T., Yamamoto, T., Khush, G. S., and Mew, T. W. 1991. Breeding of near-isogenic lines of rice with single genes for resistance to bacterial blight pathogen (Xanthomonas campestris pv. oryzae). Jpn. J. Breed. 41: 523-529.

21. Ona, I., Vera Cruz, C. M., Nelson, R. J., Leach, J. E., and Mew, T. W. 1998. Epidemic development of bacterial blight on rice carrying resistance genes $X a-4, X a-7$, and $X a-10$. Plant Dis. 82:1337-1340.

22. Ou, S. H. 1985. Rice Diseases. 2nd ed. Commonwealth Mycological Institute, Kew, England.

23. Parlevliet, J. E. 1979. Components of resistance that reduce the rate of epidemic development. Annu. Rev. Phytopathol. 17:203-222.

24. Shaner, G., and Finney, R. E. 1977. The effect of nitrogen fertilization on the expression of slow-mildewing resistance in Knox wheat.
Phytopathology 67:1051-1056.

25. Swings, J., van der Mooter, M., Vauterin, L., Hoste, B., Gillis, M., Mew, T. W., and Kersters, K. 1990. Reclassification of the causal agents of bacterial blight (Xanthomonas campestris pv. oryzae) and bacterial leaf streak (Xanthomonas campestris pv. oryzicola) of rice as pathovars of Xanthomonas oryzae (ex Ishiyama, 1922) sp. nov., nom. rev. Int. J. Syst. Bacteriol. 40:309-311.

26. Vanderplank, J. E. 1963. Plant Disease: Epidemics and Control. Academic Press, New York.

27. Yun, C. H. 1991. Molecular characterization of a repetitive element of Xanthomonas oryzae pv. oryzae. Ph.D. diss. Kansas State University, Manhattan. 